\title{
Список літератури:
}

1. Перетворення нашого світу: порядок денний у сфері сталого розвитку до 2030 року. URL: http://sdg.org.ua/ua/resources-2/344-2030-2015

2. Come on! Капіталізм, недалекоглядність, населення і руйнування планети. Доповідь римського клубу / Ернест Ульріх фон Вайцзекер, Андерс Вікман. Київ, 2019. 276 с.

3. Resolution adopted by ICOM's 34th General Assembly. URL: https://icom. museum/wp-content/uploads/2019/09/Resolutions_2019_EN.pdf

\section{НАВЧАЛЬНО-МЕТОДИЧНИЙ ПОТЕНЦІАЛ НАУКОВИХ БІБЛІОТЕК ТА АРХІВНИХ УСТАНОВ У ПОЗАКЛАСНІЙ ШКІЛЬНІЙ ОСВІТІ УКРАЇНИ}

\author{
Євген Чернухін, \\ кандидат фрілологічних наук, \\ провідний науковий співробітник, \\ Інститут педагогіки НАПН України, \\ м. Київ, \\ e-mail: geikle@hotmail.com
}

Y

часи зростаючої залученості населення до різних форм взаємодії з усесвітнім інформаційним простором спостерігаємо стрімке зменшення безпосередніх традиційних людських контактів як міжособистісного характеру, так із предметами матеріальної культури, зокрема з книжками, рукописами, витворами мистецтва, артефактами й загалом старожитностями. Не $є$ винятком і навчальний процес, у якому учні все далі заглиблюються у сприйняття інформації, зосередженої в різних формах класної роботи або збереженої на електронних носіях. Останнє ховає в собі небезпеку цифрової залежності, коли перевага надається цифровим джерелам, які заступають всі інші форми взаємодії з навколишнім оточенням.

Разом $з$ тим безпосередні міжособистісні й фізичні контакти залишаються для людини одним із основних компонентів 
і навіть умовою її психічного розвитку, оскільки лише вони потребують одночасної участі в пізнавальному процесі всього спектру людських емоцій і відчуттів, за які відповідають різні відділи головного мозку.

Утверджені ще впродовж XIX-XX ст. в шкільній педагогіці форми проведення позакласних занять і екскурсій, ознайомчих лекцій та інших заходів у різноманітних обставинах - у музеях, біля археологічних пам’яток, у навколишньому довкіллі довели їхню ефективність і дидактичну корисність для учнів різного рівня шкіл, гімназій, ліцеїв тощо.

До останнього часу за межами уваги працівників освіти України лишається низка бібліотечних та архівних закладів вищого щабля - наукові бібліотеки та державні архіви (історичні або спеціалізовані). Між тим, не існує ніяких причин для виокремлення подібних закладів від потреб шкільної освіти, яка відчуває нагальну необхідність у нових формах і методах навчання, у тому числі пов'язаних з позакласною освітою та профорієнтацією. Очевидно, однак, що для відвідування подібних закладів необхідними є дозволи й тісна співпраця з відповідними адміністраціями.

Розглянемо, до прикладу, дидактичний потенціал найбільшої наукової бібліотеки країни - Національної бібліотеки України імені В.І. Вернадського НАН України (далі - НБУВ). У структурі бібліотеки, окрім власне книжкових і газетних фондів загального призначення, мета яких задовольняти вимоги дослідників у науковій літературі, виокремлюються Інститут рукопису, Інститут книги, Інститут біографістики, а також низка спеціалізованих відділів: фондів юдаїки, музичний, образотворчого мистецтва, стародруків, історичних колекцій тощо. У фондах і колекціях цих підрозділів у формі книг і рукописів, плакатів, афіш, гравюр тощо зосереджена інтелектуальна спадщина різних народів, які мешкали на території України, а також книжки й рукописи, зокрема рідкісні, з різних куточків інших регіонів світу, зокрема глиняні таблички з Месопотамії й грецькі рукописи III-XV ст.

НБУВ формально відкрита для відвідувачів і регулярно проводить локальні внутрішні тематичні експозиції різноманітних 
матеріалів: книжок, рукописів, плакатів, афіш тощо для власних співробітників і відвідувачів. Екскурсії до Бібліотеки також не рідкість, але проведення їх відбувається майже винятково для студентів вишів з відповідною спеціалізацією. Між тим, цілком очевидно, що перелічені вище напрями діяльності окремих підрозділів НБУВ мають багато точок дотику з загальноосвітніми програмами української школи.

Насамперед це стосується загального гуманітарного складника шкільної програми. Відвідування будь-якого підрозділу НБУВ уже дає змогу вести розмову про гуманістичне виховання, про людину як носія вищого інтелектуального знання про Всесвіт, про шляхи пізнання, форми його передання й фіксації в людській культурі.

Проте не менш важливими можуть бути інші складники, як от, національно-патріотичне виховання, оскільки фонди НБУВ віддзеркалюють насамперед українську дійсність. До більш спеціалізованих сфер можна віднести питання певних дисциплін: історії України, загальної історії, окремих народів світу, питання красного письменства й загалом літератури й біографій письменників, етнографії, історії науки, друкарства й рукописних шкіл (скрипторіїв) тощо. Можуть бути підготовлені матеріали для ознайомлення з історією релігій або окремих Церков, краєзнавчі матеріали, з історії суспільної думки різних країн тощо.

Книжкові та рукописні фонди НБУВ дають змогу без докладання великих зусиль організувати такі тематичні групи експонатів, як «Тарас Шевченко», «Леся Українка», а також щодо багатьох інших письменників, поетів, науковців і суспільних діячів XIX-XX і навіть початку XXI ст. Окремо варто відзначити потенціал НБУВ щодо учнів професійно орієнтованих шкіл: музичних, художніх, учням яких було би корисним ознайомлення з фондами відповідних відділів.

Для впровадження до практики ознайомчих екскурсій, організації тематичних виставок для школярів у НБУВ необхідні спільні зусилля обох сторін. На сьогодні всі подібні заходи НБУВ мають швидше випадковий характер і готуються для конкретної (зазвичай ювілейної) події або очікуваних відвідувачів. У відді- 
лах відсутні типові набори експонатів, не відпрацьовані схеми презентації, не підготовлені тексти екскурсій, нема закріплених за текстами фахових доповідачів або екскурсоводів, повністю відсутня координація з системою шкільної освіти України.

У сучасну епоху неважко й доцільно було б також складати невеличкі тематичні блоки, свого роду «тізери», на окремі теми, які сприяли би рекламуванню можливостей НБУВ у царині позакласної шкільної освіти й надавали уяву про її фонди працівникам школи. Сучасні умови розвитку технологій і технічні методи уможливлюють створення особливих приміщень і приладів для того, щоб учні могли передивлятися частину раритетів і без безпосереднього контакту з ними, з наданням їм для розгляду цифрових копій рукописів або книжок, з можливостями збільшення зображення, перегляду сторінок, копіювання «на спогад» тощо.

Під час розроблення відповідних екскурсійних або оглядових програм допоможуть каталоги й покажчики, путівники фондів НБУВ, які регулярно друкуються в останні десятиліття, статті наукових співробітників та інших учених, які описували фонди Бібліотеки, їхню історію або використовували дотичні матеріали.

Усе викладене рівною мірою стосується фондів інших бібліотек та архівних установ України, які також можуть бути задіяні в системі шкільної освіти на різних її етапах за умов відповідної координаційної взаємодії і співробітництва сторін. Вирішальне слово у розв'язанні пропонованих завдань матиме Міністерство освіти та науки, якому підпорядковані наукові бібліотеки і яке формує освітню політику України. 